\title{
Preliminary study of the mycorrhizal community according to the age of the Afares oak (Quercus afares) of the Akfadou forest, Algeria
}

\author{
Saliha Kadi-Bennane*, Dyhia Takilt, Karima Bedad, \\ Chafia Harchaoui-Bournine, Nadjat Mezaour, Djamila Adjoud-Sadadou
}

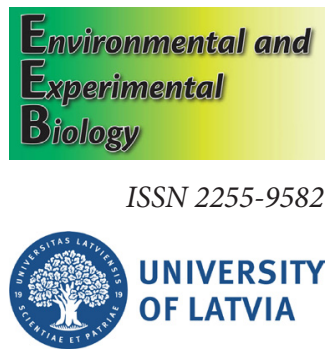

Laboratory of Production, Improvement and Protection of Plant and Foodstuffs, Faculty of Biological

Sciences and Agronomical Sciences. Mouloud Mammeri University, Tizi-Ouzou, Algeria

*Corresponding author, E-mail: kadilynda@yahoo.fr

\begin{abstract}
Afares oak (Quercus afares Pomel), a Numidian species endemic to the humid mountains of North Africa, is found in the central and eastern Algeria and the northwestern Tunisia. The aim of this study was to describe the mycorrhizal community in trees of this species at different age, in its natural environment. The study was conducted in the Akfadou forest ( $\left.36^{\circ} 41^{\prime} 57^{\prime \prime} \mathrm{N}, 4^{\circ} 33^{\prime} 25^{\prime \prime} \mathrm{E}\right)$, characterized by a fresh wet temperate climate type and less clayey soil structure. During December 2016, sampling was performed from 16 trees with size diameter of two age categories: eight trees $\leq 10$ years old and eight $\geq 60$ years. Roots were sampled at four cardinal points at a distance of $1.50 \mathrm{~m}$ from the root collar. Endomycorrhizal structures at both ages were non-existent. A specific richness of 47 ectomycorrhizal morphotypes was observed, with 18 being common to all trees. Analysis of the external mycelium showed four different types of mycorrhiza with an exploration function. The Dices similarity index indicated similarity of the ectomycorrhizal communities in trees of both age groups, especially in the composition of the short-distance exploration type community.
\end{abstract}

Key words: Afares oak, Akfadou forest, ectomycorrhiza, exploration type mycorrhiza, tree age.

Abbreviations: ECM, ectomycorrhizae; OTMR, old tree morphotype richness; TTMR, total tree morphotype richness; YTMR, young tree morphotype richness..

\section{Introduction}

Ectomycorrhizal (ECM) symbiosis is known to be a major player in the functioning of forest ecosystems (Bâ et al. 2011). Numerous species of the family Pinaceae and Fagaceae have ECM symbiosis (Smith, Read 2008). Without ECM, a healthy woodland community cannot be maintained (Rai, Varma 2010). Therefore, good knowledge on the ECM community is important for conservation and restoration of plant species in their habitats, especially in areas that are degraded due to overgrazing, climate change, stand conversion and other impacts. Knowledge of the ECM community in a particular geographical location could contribute to increasing the rate of tree adaptation and survival after afforestation.

Quercus afares Pomel is a relict tree species, representative of the restricted endemism of the Algerian and Tunisian littoral. Q. afares is considered to be a stabilized hybrid between Quercus suber and Quercus canariensis (Mir et al. 2006). It is a rather rare and threatened species with restricted distribution in the supramediterranean belt mountains, which is characterised by mean annual temperature 8 to $13^{\circ} \mathrm{C}$ and annual precipitation $\geq 600 \mathrm{~mm}$ (Quezel, Médail 2003). Many plant species are threatened with extinction worldwide, mainly because of land use changes, livestock grazing and unsustainable exploitation (Oldfield, Eastwood 2007). In the Akfadou forest in Algeria, especially in $Q$. afares habitat, intense regression of the plant cover under abusive and recurrent anthropogenic action has occurred (Quézel, Barbero 1990; Quézel 1991; Meddour 2010). It has been reported that the Afares oak area has regressed by $26.6 \%$ (Djema, Messaoudene 2009), compared to the area given by Boudy (1955) and Messaoudene (1989), and sometimes the degradation has been irreversible.

Afares oak has been the subject of several studies concerning botanical, phenological, phytogeographical, phytosociological, physiological and adaptive aspects (Boudy 1952; Maire 1952; Quezel, Bonin 1980; Messaoudene 1989; Acherar et al. 1991; Quezel, Médail 2003; Mhamdi et al. 2017). However, the symbiotic aspect, especially the mycorrhizal aspect, seems to have never been approached and, to our knowledge, functional aspects of the ectomycorrhizal community of the Afares oak are 
unknown.

Therefore, the aim this study was to describe the mycorrhizal community of the Afares oak of Kabylia (Algeria) and to compare the morphotypic richness of mycorrhiza for this oak species between young trees and old trees in its natural environment.

\section{Materials and methods}

\section{Description of study site}

The study was carried out in pure Afares oak forest of the Bouchouled canton of the Akfadou forest, in Tizi-Ouzou (Algeria). It is located in the central part of the Tellian Atlas, $36^{\circ} 41^{\prime} 57^{\prime \prime} \mathrm{N}$ and $4^{\circ} 33^{\prime} 25^{\prime \prime} \mathrm{E}, 100 \mathrm{~km}$ east of Algiers. It belongs to the phytogeographical Djurdjura sub-sector of Kabylia (Quezel, Médail 2003). It is a rugged mountainous area, consisting of a succession of ridges, extensions of the coastal range and Djurdjura Mountain, which meet at the North-East end of the massif. At an altitude of 1200 $\mathrm{m}$, the bioclimate is wet temperate to fresh wet of the supramediterranean belt.

\section{Sampling of mycorrhizas}

The study was conducted in a pure stand of Afares oak, 100 $\mathrm{m}$ near a fire trench and $50 \mathrm{~m}$ from a forest road. Sampling was carried out in December 2016 when trees were dormant and bare of foliage. Several authors report that soil enzyme activities can remain high in winter (Dormaar et al. 1984; McClaugherty, Linkins 1990) and that the turnover and metabolic activity of fine roots and ECMs of deciduous trees do not slow down during the "resting season" (Buée et al. 2005).

In vegetated ecosystems, succession of some fungal guilds occurs in tandem with plant succession (Deacon et al. 1983). These observations allows the classification of "early-stage" and "late-stage" ECM taxa. In order to distinguish between early and late stage ECMs and to assess the degree of similarity between mushroom communities of young and old trees of Afares oak, we described the ectomycorrhizal communities of 16 trees over a radius of $20 \mathrm{~m}$ chosen according to a subjective sampling based on tree diameter (age). Pressler increment borer coring was carried out to determine the age of individual trees by treering research, whereby thin cylinders of wood are retrieved using a hollow drill bit that is bored through the trunk cambial tissues and into the heartwood (Grissino-Mayer 2003). In order to avoid any adverse effects of coring on the state of health (Tsen et al. 2016) of individuals of the heritage species, samples were obtained from eight young and eight old trees. Age of thee large trees was between 60 and 111 years (trees Nos. 1, 2, 9, 12, 13, 14, 15, 16). Diameter of the young trees was $6 \pm 2 \mathrm{~cm}$, which corresponded to an age less than or equal to 10 years (trees Nos. 3, 4, 5, 6, 7, 8, 10, 11).

The ECM fungal community was evaluated in the rootzone of trees in these two age categories. Four samples of roots and soil cores were collected for each individual tree, according to the cardinal points at 1 to $1.5 \mathrm{~m}$ from the trunk under the crown of the tree, at a depth of 10 to $30 \mathrm{~cm}$. The soil temperature during sample collection was $7.6^{\circ} \mathrm{C}$ and soil $\mathrm{pH}$ was 4.5 .

\section{Laboratory analysis}

A total of 64 soil and root samples were transported on the day of collection to thelaboratory "Production, improvement and protection of plants and foodstuffs" at Mouloud Mammeri University in Tizi-Ouzou (Algeria). They were placed in labelled plastic bags and stored at $4{ }^{\circ} \mathrm{C}$ up to 15 days. A 20-cm sample of the long roots of each tree was pretreated according to the method of Phillips and Hayman (1970) in order to detect the presence of endomycorrhizal structures. One part of the root sample was gently rinsed and then observed under a stereomicroscope. The study of morphological and anatomical characteristics of the three components of the vegetative ectomycorrhizal fungi is often referred to as "morphotyping" and it widely used to study ECM communities as an end in itself to characterize fungal diversity (Horton, Bruns 2001). The observed morphotypes were preserved using a fixative $[3 \%$ formalin, $5 \%$ propionic acid and 92\% ethyl alcohol (70\%)]. Freehand anatomical sections were made and stained with lactophenol blue to complete the morphological description with anatomical features (emanating hyphae, ectomycorrhizal mantle: inner mantle, outer mantle OM), structure of rhizomorphs, shape of cystidia and Hartig's net according to the criteria of Agerer and Rambold (2004-2020), observed with a Zeiss microscope. Several authors consider that all anatomical features that include hyphae can be applied to characterize ECM (Agerer 1991a; Agerer, Rambold 2004-2020), but only four anatomical complexes are informative for recognition of fungal relationships: structure of outer mantle layers as seen in plane view, structure of rhizomorphs, shape of cystidia and features of emanating hyphae (Agerer 2006).

Individualized morphotypes are related to an exploration type according to the presence or absence of extramaterial, rhizomorphic hyphae and their mode of organization according to Agerer (2001): (i) contact (smooth structures mantle and only a few emanating hyphae, presence only of extramatricial hyphae), (ii) short distance (presence of a bulky hyphae without rhizomorphs), (iii) medium distance (presence of simple rhizomorphs with little or no differentiation), and (iv) long distance (few rhizomorphs, presence of well-differentiated rhizomorphs with central hyphae (vessel-like) of larger diameter allowing greater transport efficiency of water and nutrients). Agerer (2006) proposed that the last three groups correspond to different nutrient acquisition and translocation strategies.

The DEEMY database (Description EctoMycorrhiza, www.deemy.de) was used to determine of some morphotypes. Two ECM types were determined by 
correspondence with a sporocarp. The rest of that we could not determine received only a reference number.

\section{Statistical analysis}

Comparative analysis of the communities of the two age categories by morphotypic ectomycorrhizal richness was performed. Total tree morphotype richness (TTMR) was determined, which is the number of morphotypes observed in all trees of the two age categories. We also determined the morphotypic richness of young trees (YTMR) and the morphotypic richness of old trees (OTMR).

The similarity/dissimilarity between the ECM communities was obtained by calculating the Jaccard index of similarity:

$$
J=C /(C+S 1+S 2)
$$

and Dice similarity coefficient:

$$
D S C=2 C /(2 C+S 1+S 2)
$$

where $C$ is the number of common morphotypes between two samples, $S 1$ is the number of unique morphotypes for sample 1, and $S 2$ is the number of unique morphotypes for sample 2 .

The statistical analysis was performed using computer software BioStat 2009 (AnalystSoft Inc., Vancouver, Canada), StatBox.6 and Microsoft Excel 2013.

\section{Results}

Endomycorrhizal structures were not present in root samples from pure stands of Akfadou Afares oak trees in both age categories. Using the criteria established by Agerer and Rambold (2004-2020), root morpho-anatomical analysis allowed to determine 47 different ectomycorrhizal morphotypes. Nine morphotypes were determined to the fungal genus and four to the fungal species level (Table 1).
Morphotyping revealed the presence of morphotypes of the Basidiomycota branch, ECM formed by Amanita muscaria (L.:Fr.) Lam. and Thelephora terrestris (Pers.). Other ECMs were formed by the genera Hydnum, Russula, Lactarius, Ramaria and Quercirhiza.

$\mathrm{HBc}$ Ascomycota were well represented in the ECM community of Afares oak with, among others, species from genus Tuber of the discomycetes. ESMs formed by Dothideomycetes species Cenococcum geophilum Fr. as well as Agaricomycetes Pisolithus tinctorius (Mich.: Pers.) Coker were found.

Analysis of anatomical sections carried out for the different morphotypes highlighted the presence of a thick to medium-thick fungal mantle. Penetration of the hyphae forming the Hartig network usually did not exceed one to two layers of elongated cortical cells (Fig. 1).

From the 47 morphotypes, 18 were common, two were rare and 27 were very rare (Fig. 2). ECMs formed by Pisolithus tinctorius, Cenococcum geophylum and Quercirhiza sp. were rather commonly found.

Mean morphotypic richness of the ECM community per individual tree of $Q$. afares was TTMR $=20.18 \pm 1.68$. Similar morphotypic richness in the two age categories of Afares oak was observed: YTMR $=20.12$ for young trees and OTMR $=20.25$ for old trees (Table 2). The comparative analysis of the different ECM morphotypes at the level of the 16 characteristics revealed the presence of 18 common ECMs morphotypes, accounting for $38 \%$ of the community. Only 12 ECMs were specific to young trees and represented only $26 \%$ of the community. These can then be considered as early stage-specific ECMs of Q. afares. Seventeen ECMs were observed only in adult trees, accounting for $36 \%$ of the community; these can be considered to be late stagespecific ECMs.

Table 1. Morphological and anatomical characteristics (Agerer, Rambold 2004-2020) of common and determined ECMs anatomomorphotypes observed on Quercus afares. ${ }^{\star}$ Correspondence with the sporocarp in situ. C, contact; LD, long distance; MD, medium

\begin{tabular}{|c|c|c|c|c|c|c|c|}
\hline ECM No. & $\begin{array}{l}\text { Macroscopic } \\
\text { description }\end{array}$ & $\begin{array}{l}\text { Inner } \\
\text { mantle }\end{array}$ & $\begin{array}{l}\text { Outer } \\
\text { mantle }\end{array}$ & $\begin{array}{l}\text { Emanating } \\
\text { hyphae }\end{array}$ & $\begin{array}{l}\text { Cystidium } \\
\text { types }\end{array}$ & Rhizomorphs & $\begin{array}{l}\text { Exploration } \\
\text { type }\end{array}$ \\
\hline 1 & Ramified, greyish & $\mathrm{P}$ & $\mathrm{P}$ & $\begin{array}{l}\text { Brown, } \\
\text { frequent }\end{array}$ & - & White & $\mathrm{MD}$ \\
\hline 2 & $\begin{array}{l}\text { Unbranched, } \\
\text { constricted, brownish }\end{array}$ & $\mathrm{PP}$ & $\mathrm{P}$ & Frequent & - & Lacking & $\mathrm{SD}$ \\
\hline 3 & $\begin{array}{l}\text { Pinnate straight, } \\
\text { brown }\end{array}$ & $\mathrm{P}$ & $\mathrm{P}$ & Lacking & - & Lacking & $\mathrm{C}$ \\
\hline 4 & $\begin{array}{l}\text { Branched, straight, } \\
\text { greenish }\end{array}$ & $\mathrm{PP}$ & $\mathrm{P}$ & $\begin{array}{l}\text { Brown, } \\
\text { frequent }\end{array}$ & - & Whitish & $\mathrm{MD}$ \\
\hline 5 & $\begin{array}{l}\text { Monopodial-pinnate, } \\
\text { sinuous, brown }\end{array}$ & $\mathrm{PP}$ & $\mathrm{PP}$ & Frequent & - & Lacking & $\mathrm{SD}$ \\
\hline 6 & $\begin{array}{l}\text { Unbranched, sinuous, } \\
\text { yellowish }\end{array}$ & $\mathrm{P}$ & $\mathrm{P}$ & $\begin{array}{l}\text { Whitish } \\
\text { brown, } \\
\text { frequent }\end{array}$ & Gloeocystidia & Lacking & $\mathrm{C}$ \\
\hline
\end{tabular}
distance; P, plectenchymatous; PP, pseudo-parenchymatous; SD, short distance

continued on page 240 
Table 1. continued

\begin{tabular}{|c|c|c|c|c|c|c|c|}
\hline ECM No. & $\begin{array}{l}\text { Macroscopic } \\
\text { description }\end{array}$ & $\begin{array}{l}\text { Inner } \\
\text { mantle }\end{array}$ & $\begin{array}{l}\text { Outer } \\
\text { mantle }\end{array}$ & $\begin{array}{l}\text { Emanating } \\
\text { hyphae }\end{array}$ & $\begin{array}{l}\text { Cystidium } \\
\text { types }\end{array}$ & Rhizomorphs & $\begin{array}{l}\text { Exploration } \\
\text { type }\end{array}$ \\
\hline 7 & $\begin{array}{l}\text { Pyramidal, inflated, } \\
\text { sinuous, dark }\end{array}$ & $\mathrm{P}$ & $\mathrm{P}$ & - & Lacking & Lacking & $\mathrm{C}$ \\
\hline $\begin{array}{l}8 \text { Cenococcum } \\
\text { geophylum }\end{array}$ & $\begin{array}{l}\text { Black, unbranched, } \\
\text { grainy }\end{array}$ & $\mathrm{P}$ & $\mathrm{P}$ & $\begin{array}{l}\text { Dark, long, } \\
\text { hirsute }\end{array}$ & Lacking & Lacking & SD \\
\hline 9 Pisolithus tinctorius & $\begin{array}{l}\text { Pyramidal to } \\
\text { irregular branched, } \\
\text { sinuous, brown }\end{array}$ & $\mathrm{P}$ & $\mathrm{P}$ & Infrequent & Lacking & $\begin{array}{l}\text { Infrequent } \\
\text { with vessel-like } \\
\text { hyphae }\end{array}$ & LD \\
\hline 10 & $\begin{array}{l}\text { Irregularly branched, } \\
\text { beaded, grey }\end{array}$ & $\mathrm{P}$ & $\mathrm{P}$ & Frequent & Lacking & $\begin{array}{l}\text { Frequent } \\
\text { cotoneous }\end{array}$ & MD \\
\hline 11 & $\begin{array}{l}\text { Unbranched, } \\
\text { brownish }\end{array}$ & $\mathrm{PP}$ & $\mathrm{PP}$ & Infrequent & - & Lacking & $\mathrm{SD}$ \\
\hline 12 Quercirhiza sp.1 & $\begin{array}{l}\text { Monopodial irregular } \\
\text { branched, black }\end{array}$ & $\mathrm{P}$ & $\begin{array}{l}\text { PP, angular } \\
\text { cells }\end{array}$ & $\begin{array}{l}\text { Brown, } \\
\text { hirsute, } \\
\text { straight }\end{array}$ & $\begin{array}{l}\text { Awl-shaped, } \\
\text { bristle-like }\end{array}$ & Lacking & $\mathrm{SD}$ \\
\hline 13 & $\begin{array}{l}\text { Unbranched to } \\
\text { branched straight end } \\
\text {, yellowish }\end{array}$ & $\mathrm{P}$ & $\mathrm{P}$ & $\begin{array}{l}\text { Frequent as } \\
\text { patches }\end{array}$ & Lacking & $\begin{array}{l}\text { Frequent, } \\
\text { cotoneous }\end{array}$ & $\mathrm{MD}$ \\
\hline 14 & $\begin{array}{l}\text { Pyramidal, sinuous } \\
\text { apex roundish, dark } \\
\text { gray }\end{array}$ & $\mathrm{PP}$ & $\mathrm{PP}$ & Infrequent & - & Frequent & $\mathrm{MD}$ \\
\hline 15 & $\begin{array}{l}\text { Unbranched, bent, } \\
\text { orange }\end{array}$ & $\mathrm{PP}$ & $\mathrm{PP}$ & $\begin{array}{l}\text { Frequent, } \\
\text { white }\end{array}$ & - & Lacking & SD \\
\hline 16 & Unbranched, straight & PP & PP & Frequent & - & Lacking & SD \\
\hline 17 & Unbranched, ramified & $\mathrm{PP}$ & $\mathrm{PP}$ & Frequent & Lacking & Lacking & SD \\
\hline 18 & $\begin{array}{l}\text { Pyramidal, bent, } \\
\text { black shiny }\end{array}$ & $\mathrm{P}$ & $\mathrm{P}$ & Frequent & Lacking & $\begin{array}{l}\text { Frequent with } \\
\text { sclerote }\end{array}$ & MD \\
\hline 19 Quercirhiza sp.2 & $\begin{array}{l}\text { Unbranched, tubercle, } \\
\text { dark brown }\end{array}$ & $\mathrm{PP}$ & $\begin{array}{l}\text { PP, angular } \\
\text { cell }\end{array}$ & $\begin{array}{l}\text { Frequent, } \\
\text { dark }\end{array}$ & Lacking & Lacking & SD \\
\hline 20 Ramaria sp. & $\begin{array}{l}\text { Branched, thin; bent, } \\
\text { yellowish }\end{array}$ & $\mathrm{P}$ & $\mathrm{P}$ & Infrequent & Lacking & Frequent, white & $\mathrm{MD}$ \\
\hline 25 Russula sp.1 & $\begin{array}{l}\text { Monopodial, straight, } \\
\text { yellowish }\end{array}$ & $\mathrm{PP}$ & $\mathrm{PP}$ & $\begin{array}{l}\text { Infrequent, } \\
\text { yellowish }\end{array}$ & Lacking & Lacking & $\mathrm{C}$ \\
\hline 29 Amanita muscaria & $\begin{array}{l}\text { Monopodial, bent, } \\
\text { yellowish, silvery }\end{array}$ & $\mathrm{P}$ & $\mathrm{P}$ & $\begin{array}{l}\text { Infrequent, } \\
\text { white }\end{array}$ & Lacking & $\begin{array}{l}\text { Frequent, white } \\
\text { with clamp }\end{array}$ & $\mathrm{MD}$ \\
\hline 30 Lactarius sp. 1 & $\begin{array}{l}\text { Pyramidal, smooth, } \\
\text { greenish }\end{array}$ & $\begin{array}{l}\mathrm{PP}, \\
\text { angular } \\
\text { cells }\end{array}$ & $\mathrm{P}$ & Infrequent & - & Lacking & $\mathrm{C}$ \\
\hline 31 Lactarius sp.2 & $\begin{array}{l}\text { Unbranched, bent, } \\
\text { smooth, orange to } \\
\text { yellowish }\end{array}$ & $\begin{array}{l}\mathrm{PP}, \\
\text { angular } \\
\text { cells }\end{array}$ & $\mathrm{P}$ & Lacking & $\begin{array}{l}\text { Flask-shaped } \\
\text { with apical } \\
\text { knob }\end{array}$ & Lacking & $\mathrm{C}$ \\
\hline $\begin{array}{l}35 \text { Thelephora } \\
\text { terrestris }^{\star}\end{array}$ & $\begin{array}{l}\text { Monopodial, straight, } \\
\text { yellowish }\end{array}$ & $\mathrm{P}$ & $\mathrm{P}$ & Lacking & Lacking & $\begin{array}{l}\text { Infrequent } \\
\text { vessel-like } \\
\text { hyphae }\end{array}$ & MD \\
\hline 37 Hydnum sp.* & $\begin{array}{l}\text { Pyramidal, bent, } \\
\text { grainy, white }\end{array}$ & $\mathrm{P}$ & $\mathrm{P}$ & - & 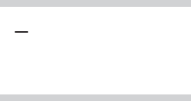 & Frequent white & MD \\
\hline 39 Tuber sp. & $\begin{array}{l}\text { Unbranched, straight, } \\
\text { grainy, orange }\end{array}$ & $\mathrm{P}$ & $\mathrm{PP}$ & $\begin{array}{l}\text { Frequent, } \\
\text { yellowish }\end{array}$ & $\begin{array}{l}\text { Awl-shaped; } \\
\text { bristle-like }\end{array}$ & Lacking & $\mathrm{SD}$ \\
\hline 42 Russula sp.2 & $\begin{array}{l}\text { Monopodial- } \\
\text { pyramidal, orange }\end{array}$ & $\mathrm{P}$ & - & Frequent & $\begin{array}{l}\text { Flask-shaped } \\
+ \text { apical knob }\end{array}$ & Infrequent & $\mathrm{MD}$ \\
\hline
\end{tabular}


According to the first two axes of the factorial correspondence analysis (total inertia of $86 \%$ ), a set of common ECMs $(\mathrm{C})$ in both young trees $(\mathrm{Y})$ and old trees (O) was distinguished. The highest contributions of 3.40 to axis 1 (Fig. 3) were for the ECMs common to all trees on the positive side of the axis 1 (C). The two groups formed on the negative side of axis 1 distinguished the ECMs absent in young trees (Y): T3, T4, T5, T6, T7, T8, T11 and those absent in old trees (O): T1, T2, T9, T10, T12, T13, T14, T15, T16.

The Jaccard's index of similarity $(J=0.33)$, and Dice similarity coefficient $(D S C=0.62)$ indicated similarity of 45 to $62 \%$ for the ECM between the age categories of the trees (Table 3). This indicated similar ectomycorrhizal communities between the two age categories of the Afares oak population of the Akfadou forest.

The emanating hyphae of morphotypes were classified into the four types of exploration described by Agerer (2001). Short roots revealed the presence of the different exploration types in all the trees, but there were greater numbers of the medium and short-distance types. Longdistance and contact type exploration were less represented (Fig. 4).

The distribution of exploration types at the level of the ECM community of the short roots of the Afares oak showed 20 morphotypes (43\%) for medium-distance exploration, 13 ECMs (28\%) for the short-distance type, 10 ECMs (21\%) for the contact type and four ECMs (8\%) for the long-distance type. However, in the community common to both age groups, the proportion of exploration groups was reversed with eight short-distance types ECMs (44\%), and six medium-distance types (33\%; Fig. 5).

The Jaccard's index of similarity $(J=0.61)$, and Dice similarity coefficient $(D S C=0.76)$ showed similarity of the short-distance type between the tree age groups. However, the contact, medium-distance and long-distance types showed heterogeneity of the ECM community between the two stages (Table 3).

\section{Discussion}

The observation of the fungal structures in the cells of short and long roots of $Q$. afares confirmed the absence of arbuscules, vesicles and pelotons, as already reported by several authors for Quercus species (Smith, Read 2008; Garbaye 2013).

The presence of morphotypes of Basidiomycota and Ascomycota is common among forest species. Among the Basidiomycota, the ECMs formed by the Russula genus were reported by Beenken (2004) in Quercus, ECMs formed by the Lactarius genus were described by Luppi and Gautero (1967) in Quercus petraea and Palfner (1998) in Quercus robur. The ECMs formed by Amanita muscaria (L.:Fr.), and Laccaria, Hydnum and Ramaria genus were reported by Agerer and Rambold (2004-2020) in Quercus.
Ascomycota are well represented in the ECM community of Afares oak with, among others, the discomycetes genus Tuber already observed in Q. robur (Luppi, Gautero 1967) and in Q. suber and Quercus ilex (Lancellotti, Franceschini 2013). We noted the presence of the ECM formed by loculoascomycetes Cenococcum geophilum, previously found in Q. ilex (Agueda et al. 2001), Q. suber (Lancellotti, Franceschini 2013; Kadi-Bennane 2016) and in Quercus cerris, Quercus frainetto, and Q. robur in Romania (Fodor et al. 2011). The ECM formed by Pisolithus tinctorius was observed in Q. ilex (Agueda et al. 2001). This ECM was abundantly observed in Q. suber at all age stages (KadiBennane 2016).

It appears that Afares oak has fungal partners common to species of the Fagaceae family and to the same genus. A dominance of Russulaceae, Cortinariaceae, Thelephoraceae, and Inocybaceae occurs in Quercus, Fagus and Castanea (Ortega, Lorite 2007). The ectomycorrhizal community is similar for species of Fagaceae and the genus Quercus (Garbaye 2013; Reis et al. 2017). Moreover, several authors reported that Quercus species have a similar community of ectomycorrhizal partners, which consists of Basidiomycota like Russulaceae (Russulales), Thelephoraceae (Thelephorales), Boletus (Boletales), Cortinariaceae, Inocybaceae and Amanitaceae (for the majority of Agaricales) (Ortega, Lorite 2007; Garbaye 2013).

Elongation of cortical cells was observed in anatomical sections, reflecting the efficiency of the symbiosis. This form of cortical cells in contact with the Hartig network offers a greater intensity of exchange between the two partners (Burgess et al. 1994). This anatomical characteristic confirms symbiotic activity in this vegetative rest period. Indeed, it was reported that the metabolic activity of fine roots and ECMs of deciduous trees does not slow down during the 'resting season' (Buée et al. 2005).

Our study allowed to distinguish 47 ECMs. This morphotype richness was similar to the species richness of ECMs observed previously by in oak forests -43 species (Sharma 2017). Of the ECMs, 18 anatomo-morphotypes were common, two were rare and 27 were very rare. Higher proportion of infrequent morphotypes or even present only once, occurs in the majority of ectomycorrhizal communities (Garbaye 2013; Kadi-Bennane 2016). It is assumed that, from a functional point of view, the dominant fungal partners that account for most of the fungal biomass would be the most relevant in nutrient uptake and the least expensive in terms of nutrient uptake energy balance (Walker et al. 1999). It has been considered that the typical fungal partners participating in the beginning of succession, like Cenococcum, Inocybe, Laccaria, Pisolithus, and Tuber, tend to be persistent in disturbed habitats (Krpata et al. 2008).

The ECMs formed by Pisolithus tinctorius, Cenococcum geophylum and Quercirhiza sp.1 are among the common 

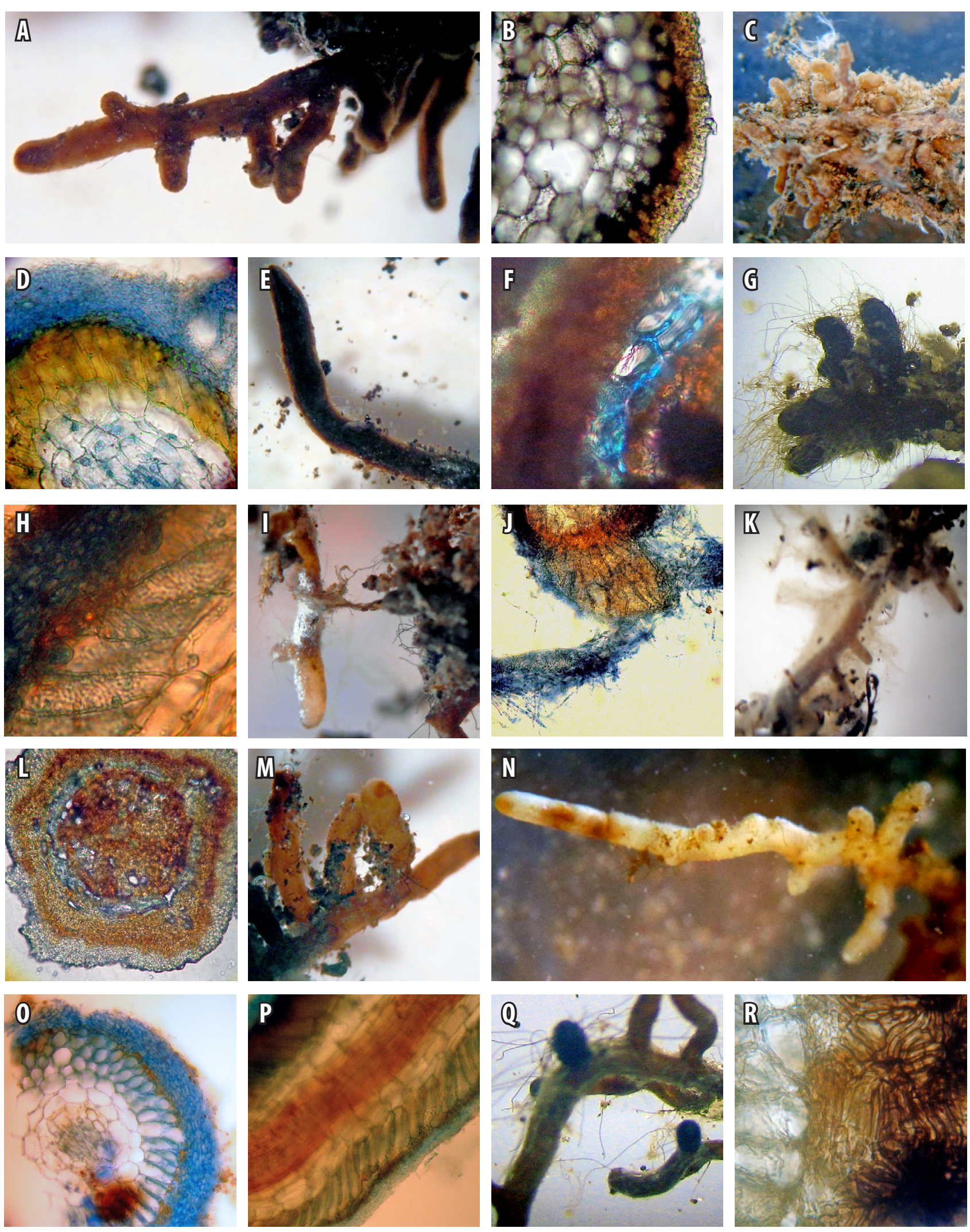

Fig. 1. Examples of ectomycorrhizae observed on roots of Quercus afares in natural forest of Akfadou (Algeria). A, ECM Lactarius sp.1: contact exploration type, simple with orange color $(\times 20)$. B, ECM Lactarius sp.1: cross section, thick and compact pseudoparenchymatous mantle. C, ECM Pisolithus tinctorius long-distance exploration type $(\times 40)$. D, ECM P. tinctorius: cross section, with plectenchymatous continued on page 243 


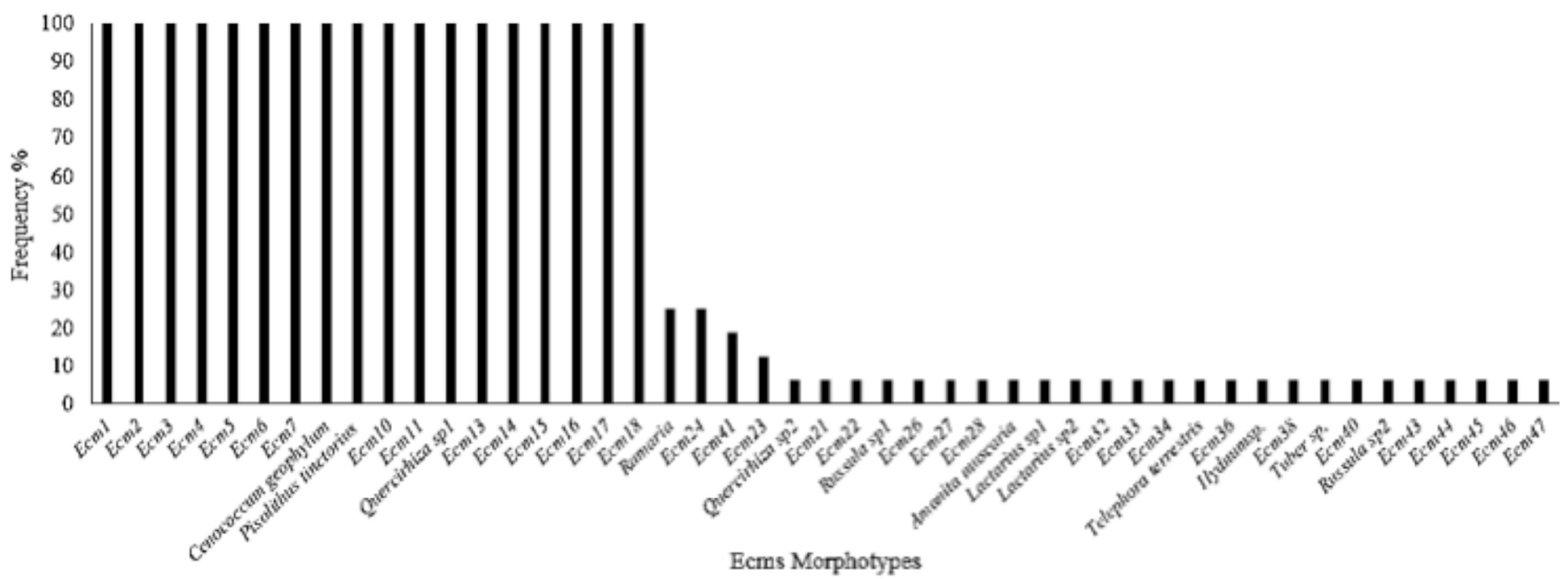

Fig. 2. Relative frequency of ectomycorrhizal morphotypes of Quercus afares in the Akfadou forest (Tizi-Ouzou, Algeria).

anatomo-morphotypes. They are known for their efficiency in the translocation of water and phosphorus (Reis et al. 2017). Pisolithus tinctorius was reported as a typical earlystage ECM fungus, which is well adapted to low $\mathrm{pH}$ and high temperatures of anthracite and hard coal spoils (Marx 1975). This common and widespread multi-host species is known from many highly disturbed sites (Marx 1977). Furthermore, the presence of Quercirhiza sp. morphotypes is a high stress indicator in Quercus (Kovacs et al. 2000) and Cenococcum geophylum presence is a soil dehydration indicator (Garbaye 2013).

According to species richness, the a diversity of fungal partners per root system of a tree is on average about eight to 20 types (Allen et al. 2003). For Afares oak, the mean morphotypic richness was $20.18 \pm 1.68$ (YTMR $=20.12$ in young trees and OTMR $=20.25$ in old trees). The similarity of ECM communities and the presence of common morphotypes can be explained by the maintenance of mycorrhizae from the early or pioneer stage (Guinberteau et al. 1990). In natural environments, late-stage ECM fungi colonize the roots of young plants via the rhizomorphs of emanating hyphae (Fleming 1983), referred to as the "wood-wide-web" (Helgason et al. 1998). They persist for a very long time in the state of "background noise" and rarely completely disappear. Ectomycorrhizal partners might occupy the periphery of the expanding root system even of old trees (Arnold 1991). For Afares oak of the Akfadou forest, our observations allowed to describe a similar ectomycorrhizal community between the two age categories of the population. In addition, there was an abundance of the medium-distance with short-distance exploration morphotypes. In forest ecosystems, "late stage fungi" can be found on roots closest to the trunk of the tree and "early stage fungi" on roots farthest from the base of the

Table 2. Richness and similarity indices of the ectomycorrhizal community in two age groups of Quercus afares of Akfadou forest (TiziOuzou, Algeria)

\begin{tabular}{|c|c|c|c|c|c|c|c|}
\hline Age group & $\begin{array}{c}\text { Specific } \\
\text { morphotype } \\
\text { richness }\end{array}$ & $\begin{array}{c}\text { Total } \\
\text { morphotype } \\
\text { richness per } \\
\text { category }\end{array}$ & $\begin{array}{c}\text { Morphotype } \\
\text { richness per } \\
\text { tree }\end{array}$ & $\begin{array}{c}\text { Common } \\
\text { ECMs }\end{array}$ & $\begin{array}{c}\text { Total } \\
\text { morphotype } \\
\text { richness }\end{array}$ & Jaccard index & Dices index \\
\hline Young trees & 12 & 30 & 20.12 & \multirow{2}{*}{18} & \multirow{2}{*}{47} & \multirow{2}{*}{0.33} & \multirow{2}{*}{0.55} \\
\hline Old trees & 17 & 35 & 20.25 & & & & \\
\hline
\end{tabular}

Fig. 1. continued

mantle and rhizomorphs $(\times 400)$. E, ECM 42: monopodial and yellowish brown color $(\times 40)$. F, ECM 42: cross section, plectenchymatous mantle with presence of tannin cells $(\times 400)$. G, ECM Quercirhiza sp.1: monopodial and dark color with emanating hyphea $(\times 20)$. $\mathrm{H}$, Quercirhiza sp.1: longitudinal section, pseudoparenchymatous mantle and para-epidermal Hartig network. I, ECM Thelephora terrestris $(\times 40)$. J, ECM T. terrestris: longitudinal section, compact plectenchymatous mantle with rhizomorph $(\times 400)$. K, ECM 1 : ramified and greyish, medium-distance type. L, ECM 1: cross section, thick plectenchymatous mantle with compact outer mantle. M, ECM 25: monopodial-pyramidal, orange $(\times 20)$. N, ECM 25: cross section, pseudoparenchymatous mantle and periepidermal Hartig network on one layer cell $(\times 400)$. O, ECM 31: monopodial, straight, yellowish contact type $(\times 40)$. P, ECM 31: longitudinal section, contact exploration type, pseudoparenchymatous mantle with angular cells $(\times 400)$. Q, ECM Cenococcum geophylum: with rather thick emanating hyphea $(\times 40)$. R, C. geophylum: cross section, with star-like tightly glued hyphae, cenococcoid mantle $(\times 400)$. 


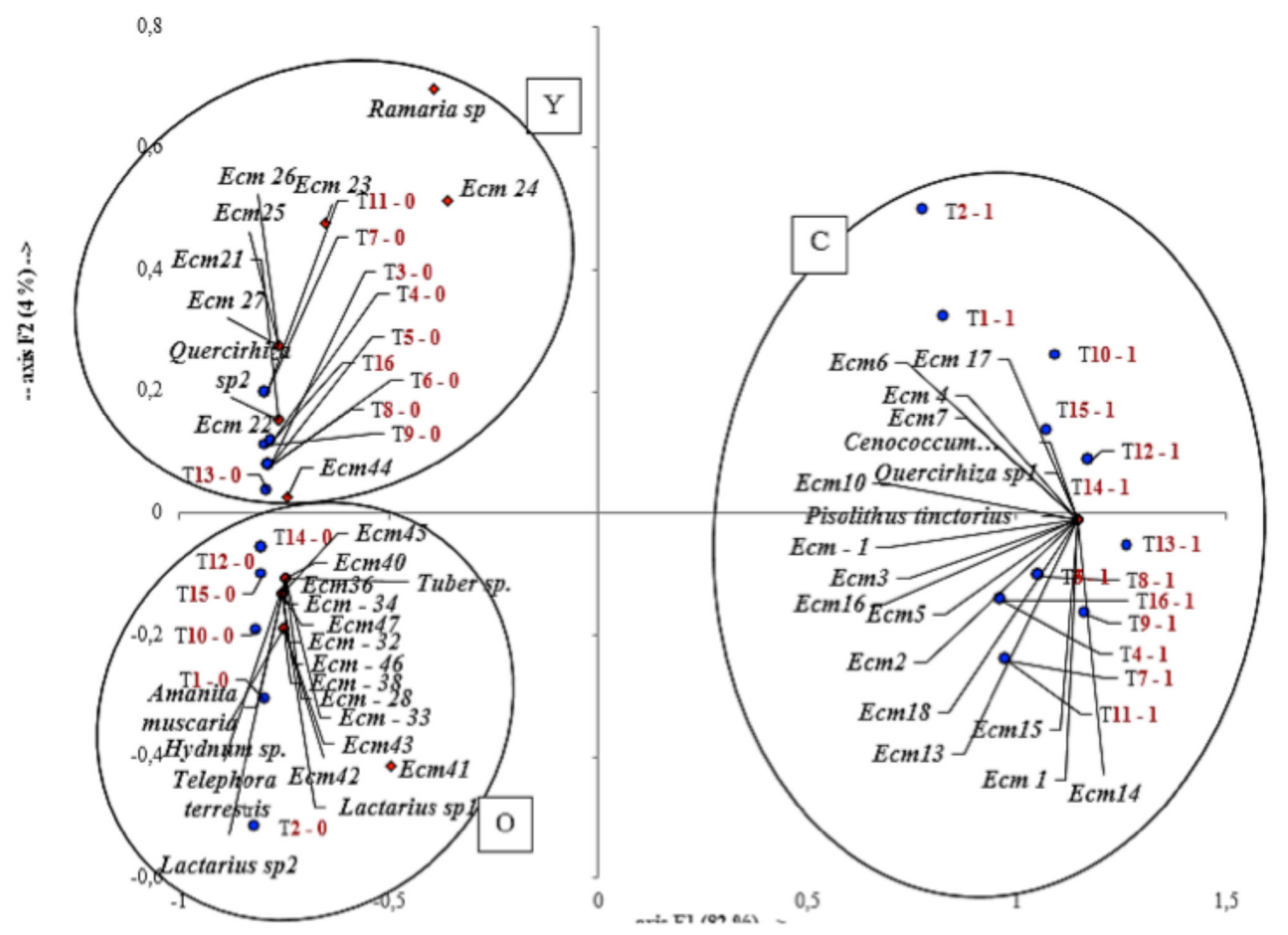

Fig. 3. Projection of individual trees and ECM types on the first two axes of the factorial correspondence analysis ( $86 \%$ inertia) of Afares oak Quercus afares of Akfadou forest (Algeria).

tree (Ford et al. 1980; Wolfe et al. 2009). Hyphal connections can also maintain physiological continuity between a tree and seedlings (Simard et al. 1997). Neighboring tree species identity shaped the ECMs community structure of the host, and the effects were specific to host-neighbor combination (Hubert, Gehring 2008); tree species may serve as reservoirs of ECM inoculation to one another. The theory of systematic change during successions has been reviewed and conservation in large part of the early successional species was reported, and that most types of mycorrhizae can dominate at any stage of ecosystem development (Dickie et al. 2013). The shifts the vegetation composition and function, including photosynthesis efficiency and nutrient requirements, are still considered strong determinants of ECM fungi successional traits (Buscot 2015).

The medium and long-distance types with emanating hyphae are more efficient for transport, while the shortdistance types are more efficient in absorption (Lilleskov et al.2011). In addition, it should be kept in mind that medium and long exploration types require large amounts of carbon to establish an extensive mycelial exploration network (Baier et al. 2006). In conditions of reduced C supply from trees, this carbon is not available during drought and vegetative rest periods, which favours species that produce little external mycelium, such as the contact and shortdistance types (Lilleskov et al. 2011). The richness of the medium-distance type ECMs can be explained by the poor forest soils in Mediterranean regions, with low amounts of available nitrogen and phosphorus. This creates a need for Afares oak to ally with fungal partners, despite their costly energy needs and the state of vegetative rest at the time of sampling.

Jaccard's index of similarity and Dice similarity coefficient indicated similarity of the communities in types of exploration for the two age groups. However, the short distance type most represented among the common community. Detailed analysis allowed to show differences in the ECM communities, in particular for the contact, medium distance and long distance types among the tree age categories.

The similarity of the afares oak tree communities of the

Table 3. Comparative distribution of exploration type and similarity index by age category of Akfadou forest Quercus afares

$\begin{array}{lcccccc}\text { Exploration type } & \text { Young tree ECMs } & \text { Old tree ECMs } & \text { Common ECMs } & \text { Jaccard index } & \text { Dices index } \\ \text { Contact } & 2 & 5 & 3 & 0.30 & 0.46 \\ \text { Short distance } & 3 & 2 & 8 & 0.61 & 0.76 \\ \text { Medium distance } & 5 & 9 & 6 & 0.30 & 0.46 \\ \text { Long distance } & 2 & 1 & 1 & 0.25 & 0.40\end{array}$



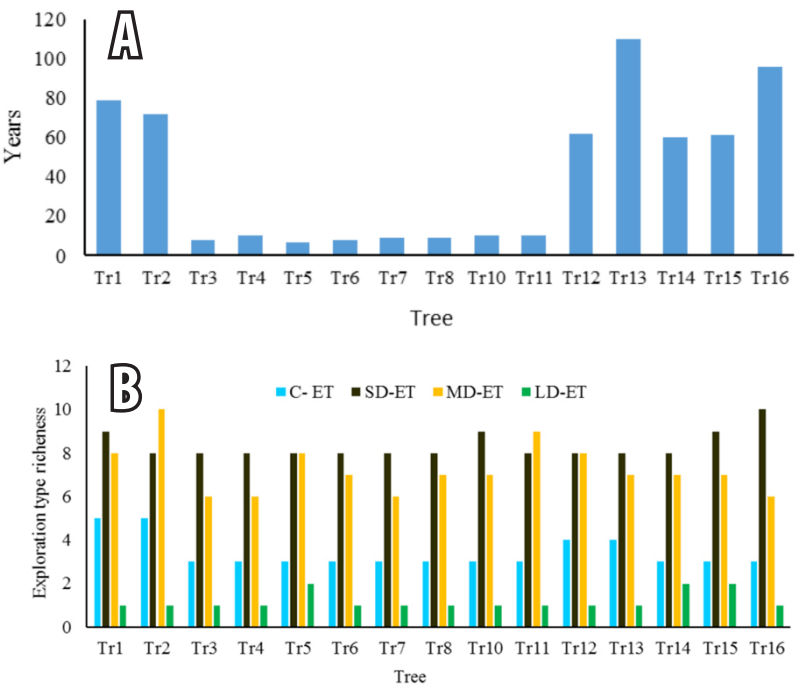

Fig. 4. Individual variability of age (A) and richness of exploration type (B) in Quercus afares of Akfadou forest (Algeria). C-ET, contact exploration type; $\mathrm{SD}-\mathrm{ET}$, short distance exploration type; MD-ET, medium distance exploration type; LD-ET, long distance exploration type.

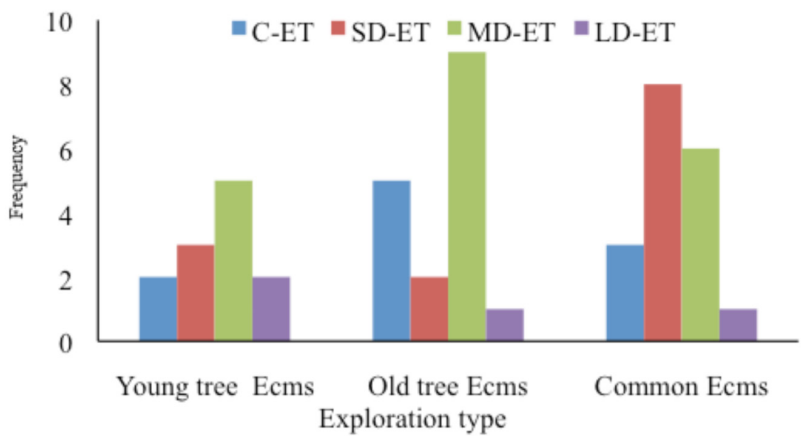

Fig. 5. Distribution of exploration types in the ectomycorrhizal community of Quercus afares according to age categories in the Akfadou forest (Tizi-Ouzou, Algeria). C-ET, contact exploration type; SD-ET, short distance exploration type; MD-ET, medium distance exploration type; LD-ET, long distance exploration type.

two ages can be explained by the social relations and the "source - sink" mode (Simard et al. 2003). These transfer processes imply that nutrient, carbon and water deficiencies for a single species can be overcome by transfer strategies between individuals of the same species and between species of the same plant community (Van der Heijden et al. 1998). The networking by fungi can be made not only by long distance exploration types but also by short distance types when the roots of the trees spatially overlap (Horton, Bruns 2001). The ECM can interconnect roots of the same or different species (Simard, Durall 2004).

\section{Conclusions}

Quercus afares of the Akfadou forest (Tizi-Ouzou, Algeria) has common mycorrhizal status of species of the Fagaceae family and more precisely those of the same genus.
Endomycorrhizal structures were absent, and the typical anatomo-morphotypes were mainly associated with subbranching of Ascomycota and Basidiomycota with the presence of ectomycorrhizae formed by Cenococcum geophilum, Pisolithus tinctorius and Quercirhiza spp. Our study found similarity in the composition of the ectomycorrhizal community between the two age categories during the vegetative rest of Afares oak. Functional analysis of the morphotypes showed the short and mediumdistance exploration types were more common in the ectomycorrhizal community of Afares oak, regardless of the age category.

\section{References}

Acherar M., RambaL S., Lepart J. 1991. Évolution du potentiel hydrique foliaire et de la conductance stomatique de quatre chênes méditerranéens lors d'une période de dessèchement. Ann. For. Sci. 48: 561-573.

Agerer R. 2001. Exploration types of ectomycorrhizae. A proposal to classify ectomycorrhizal mycelial systems according to their patterns of differentiation and putative ecological importance. Mycorrhiza 11: 107-114.

Agerer R. 2006. Fungal relationships and structural identity of their ectomycorrhizae. Mycol. Progr. 5: 67-107.

Agerer R., Rambold G. 2004-2020. DEEMY - An Information System for Characterization and Determination of Ectomycorrhizae. München, Germany. www.deemy.de

Agueda B., Fernandez M., De Miguel A.M. 2001. Ectomycorrhizae present in the truffle plantation 'Los Quejigares' (Soria). Proceedings of the III Spanish Forestry Congress, Granada, pp. 100-106.

Allen M.F. Swenson W., Querejeta J.I., Egerton-Warburton L.M., Treseder K.K. 2003. Ecology of mycorrhizae: A conceptual framework for complex interactions among plants and fungi. Annu. Rev. Phytopathol. 41:271-303.

Arnold E. 1991. Decline of ectomycorrhizal fungi in Europe. Agric. Ecosyst. Environ. 35: 209-244

BâA., Duponnois R., Diabaté M., Dreyfus B.2011.Les Champignons Ectomycorhiziens des Arbres Forestiers en Afrique de l'Ouest: Méthodes D'étude, Diversité, Écologie, Utilisation en Foresterie et Comestibilité. IRD Éditions, 252 p.

Baier R., Ingenhaag J., Blaschke H., Göttlein A., Agerer R. 2006. Vertical distribution of an ectomycorrhizal community in upper soil horizons of a young Norway spruce (Picea abies [L.] Karst.) stand of the Bavarian Limestone Alps. Mycorrhiza 16: 197-206.

Beenken L. 2004. Die Gattung Russula. Untersuchungen zu ihrer Systematik anhand von Ektomykorrhizen. PhD Thesis. Ludwig Maximilians Universität München, Munich. 414 p.

Boudy P. 1952. Guide du Forestier en Afrique du Nord. La maison rustique, Paris. 489 p.

Buée M., Vairelles D., Garbaye J. 2005. Year-round monitoring of diversity and potential metabolic activity of the ectomycorrhizal community in a beech (Fagus silvatica) forest subjected to two thinning regimes. Mycorrhiza 15: 235-245.

Boudy P. 1955. Economie Forestière Nord-Africaine. Tome 4, Edition Larose. 247 p.

Burgess T., Dell B., Malajczuk N. 1994. Variation in mycorrhizal development and growth stimulation by 20 Pisolithus isolates 
inoculated on to Eucalyptus grandis W. Hill ex Maiden. New Phytol. 127: 731-739.

Buscot F.2015. Implication of evolution and diversity in arbuscular and ectomycorrhizal symbioses. J. Plant Physiol. 172: 55-61.

Deacon J., Donaldson S., Last F. 1983. Sequences and interactions of mycorrhizal fungi on birch. Plant Soil 71:257-262.

Dickie I.A., Martínez-García L.B., Koele N., Grelet G.A., Tylianakis J.M., Peltzer D.A., Richardson S. 2013. Mycorrhizas and mycorrhizal fungal communities throughout ecosystem development. Plant Soil 367: 11-39.

Djema A., Messaoudene M. 2009. The Algerian forest: Current situation and prospects. In: Palahí M., Birot Y., Bravo F., Gorriz E. (eds) Modelling, Valuing and Managing Mediterranean Forest Ecosystems for Non-Timber Goods and Services. EFI Proceedings No. 57, pp. 17-27.

Dormaar J.F., Johnston A., Smoliak S. 1984. Seasonal changes in carbon content, and dehydrogenase, phosphatase, and urease activities in mixed prairie and fescue grassland Ah horizons. J. Range Manage. 37: 31-35.

Eastwood A., Oldfield S. 2007. The Red List of Oaks. IUCN. Fauna and Flora International, Cambridge.

Fleming L.V. 1983. Succession of mycorrhizal fungi on birch: infection of seedlings planted around mature trees. Plant Soil 71: 263-267.

Fodor E., Timofte A., Geambau T. 2011. Mycorrhizal status of several Quercus species in Romania (Quercus cerris, Q. frainetto, Q. robur) and the optimization perspective of growth conditions for in vitro propagated plants transplanted in the field. Ann. Forest Res. 54: 57-71.

Ford E.D., Mason P.A., Pelham J.1980. Spatial patterns of sporophore distribution around a young birch tree in three successive years. Trans. British Mycol. Soc. 75: 287-296

Garbaye J. 2013. La Symbiose Mycorhizienne: Une Association Entre les Plantes et les Champignons. Editions Quae, Versailles. $251 \mathrm{p}$.

Grissino-Mayer H.D. 2003. A manual and tutorial for the proper use of an increment borer. Tree Ring Res. 59: 63-79.

Guinberteau J., Ducamp M., Poitou N., Mamoun M., Olivier J.M. 1990. Ecology of various competitors from an experimental plot of Pinus pinaster inoculated with Suillus granulatus and Lactarius deliciosus. Agric. Ecosyst. Environ. 28: 161-165.

Helgason T., Daniell T.J., Husband R., Fitter A.H., Young J.P.W. 1998. Ploughing up the wood-wide web? Nature 394: 431-431.

Horton T.R., Bruns T.D. 2001. The molecular revolution in ectomycorrhizal ecology: peeking into the black-box. Mol. Ecol. 10: 1855-71

Hubert N.A., Gehring C.A. 2008. Neighboring trees affect ectomycorrhizal fungal community composition in a woodland-forest ecotone. Mycorrhiza 18: 363-374

Kadi-Bennane S. 2016. Les Ectomycorhizes du chêne liège : effet des facteurs environnementaux. Thèse de doctorat, Université Mouloud Mammeri. 167 p.

Kovacs G., Pausch M., Urban A. 2000. Diversity of ectomycorrhizal morphotypes and oak decline. Phyton 40: 109-116.

Kremer A., Petit R. J., Ducousso A. 2002. Biologie évolutive et diversité génétique des chênes sessile et pédonculé. Rev. For. Fr. 54: 111-130.

Krpata D., Peintner U., Langer I., Fitz W.J., Schweiger P. 2008. Ectomycorrhizal communities associated with Populus tremula growing on a heavy metal contaminated site. Mycol. Res. 112: 1069-1079.

Lancellotti E., Franceschini A. 2013. Studies on the ectomycorrhizal community in a declining Quercus suber L. stand. Mycorrhiza 23: 533-542.

Lilleskov E.A., Hobbie E.A., Horton TR. 2011. Conservation of ectomycorrhizal fungi: exploring the linkages between functional and taxonomic responses to anthropogenic $\mathrm{N}$ deposition. Fungal Ecol. 4: 174-183.

Luppi A.M., Gautero C. 1967. Researches on the mycorrhizae of Quercus rober, Q. petraea and Q. pubescens in Piedmont. Allionia 13: 148.

Maire R. 1952. Flore de l'Afrique du Nord (Maroc, Algérie, Tunisie, Tripolitaine, Cyrénaïque et Sahara). Lechevalier, Paris, 371 p.

Marx D.H. 1975. Mycorrhizae and establishment of trees on stripmined land. Ohio J. Sci. 75: 288-297

Marx D.H. 1977. Tree host range and world distribution of the ectomycorrhizal fungus Pisolithus tinctorius. Can. J. Microbiol. 23: $217-223$

McClaugherty C.A., Linkins A.E. 1990. Temperature responses of enzymes in two forest soils. Soil Biol. Biochem. 22: 29-33.

Messaoudene M. 1989. Dendroécologie et productivité de Quercus afares Pomel et Quercus canariensis Willd. dans les massifs forestiers de l'Akfadou et de Beni Ghorbi en Algérie. Thèse Docteur en Sciences. Université of Aix-Marseille III, France.

Mir C., Toumi L., Jarne P., Sarda V., Di Giusto F., Lumaret R. 2006. Endemic North African Quercus afares Pomel originates from hybridisation between two genetically very distant oak species (Q. suber L. and Q. canariensis Willd.): evidence from nuclear and cytoplasmic markers. Heredity 96: 175-184.

Mhamdi S., Brendel O., Montpied P., Ben Yahia K., Saouyah N., Hasnaoui B., Dreyer E. 2017. Inter-specific differences in leaf phenology, growth of seedlings of cork oak (Quercus suber L.), zeen oak (Quercus canariensis Willd.) and their hybrid afares oak (Quercus afares Pomel) in the nursery. Int. J. Biol. Ecol. Eng. 11: 748-752.

Ortega A., Lorite J. 2007. Macrofungi diversity in cork-oak and holm-oak forests in Andalusia (southern Spain); an efficient parameter for establishing priorities for its evaluation and conservation. Centr. Eur. J. Biol. 2: 276-296.

Palfner G. 1998. Lactarius chrysorrheus. In: Agerer R. (ed) Colour Atlas of Ectomycorrhizae. Einhorn-Verlag Eduard Dietenberger, Schwabisch Gmund. p. 121.

Phillips S.M., Hayman D.S. 1970. Improved procedures for clearing roots and staining parasitic and vesicular-arbuscular mycorrhizal fungi for rapid assessment of infection. Trans. British Mycol. Soc. 55: 158-162.

Quezel P., Médail F. 2003. Ecologie et Biogéographie des Forêts du Bassin Méditerranéen. Elsevier, Paris. 592 p.

Quezel P., Bonin G. 1980. Les forêts feuillues du pourtour méditerranéen, constitution, écologie, situation actuelle, perspectives. Rev. For. Fr. 32: 253-268

Rai M., Varma A. (eds) 2010. Diversity and Biotechnology of Ectomycorrhizae. Soil Biology Vol. 25. Springer, Heidelberg.

Reis F., Tavares R.M., Baptista P.,Lino-Neto T.2017. Mycorrhization of Fagaceae forests within Mediterranean ecosystems. In: Varma A. Prasad R., Tuteja N. (eds) Mycorrhiza - Function, Diversity, State of the Art. Springer, Berlin, pp. 75-97.

Sharma R. 2017. Ectomycorrhizal mushrooms: their diversity, ecology and practical applications. In: Varma A., Prasad R., Tuteja N. (eds) Mycorrhiza - Function, Diversity, State of the Art. Springer, Berlin, pp. 99-131.

Simard S.W., Durall D.M., Jones M.D.1997. Carbon allocation and carbon transfer between Betula papyrifera and Pseudotsuga menziesii seedlings using a ${ }^{13} \mathrm{C}$ pulse-labeling method. Plant 
Soil 191: 41-45

Simard S.W., Jones M.D., Durall D.M. 2003. Carbon and nutrient fluxes within and between mycorrhizal plants. In: Van der Heijden, M.G.A., Sanders I.R (eds) Mycorrhizal Ecology. Ecological Studies. Springer Verlag, Heidelberg, pp. 33-74.

Simard S.W., Durall D.M. 2004. Mycorrhizal networks: a review of their extent, function, and importance. Can. J. Bot. 82: 11401165.

Smith S.E., Read, D.J. 2008. Mycorrhizal Symbiosis. $2^{\text {nd }}$ Ed. Academic Press, Toronto, 605 p.

Tsen E.W., Sitzia, T., Webber B.L. 2016. To core, or not to core: the impact of coring on tree health and a best-practice framework for collecting dendrochronological information from living trees. Biol. Rev. 91: 899-924.

Van der Heijden M.A.G., Klironomos J.N., Ursic M., Moutoglis P., Streitwolf-Engel R., Boller T., Wiemken A. Sanders I.R. 1998. Mycorrhizal fungal diversity determines plant biodiversity, ecosystem variability and productivity. Nature 396: 69-72.

Walker B., Kinzig A., Langridge J. 1999. Plant attribute diversity, resilience, and ecosystem function: the nature and significance of dominant and minor species. Ecosystems 2: 95-113.

Wolfe B.E., Parrent J.L., Koch A.M., Sikes B.A., Gardes M., Klironomos J.N. 2009. Spatial heterogeneitiy of mycorrhizal populations and communities: scales and mechanism. In: Azcón-Aguilar C. et al. (eds) Mycorrhizas-Functional Processes and Ecological Impact. Springer, Berlin, pp. 167-185. 